\title{
Possible Sodium and D-Glucose Cotransport in Isolated Jejunal Epithelium of Children
}

\author{
ETIENNE GRASSET, MARTINE HEYMAN, ANNE MARIE DUMONTIER, H. LESTRADET, AND \\ JEHAN FRANÇOIS DESJEUX \\ Groupe de Recherche sur le Diabète et la Nutrition chez l'Enfant, INSERM U 83, and Département de Pédiatrie, \\ Université Paris VII, Hôpital Hérold PARIS, France.
}

\begin{abstract}
Summary
Some experimental data in human jejunum suggest a $\mathrm{Na}$ dependence for glucose absorption and a glucose dependence for $\mathrm{Na}$ absorption. However, the relationship between these two transport processes is not yet known. $\mathrm{Na}^{+}$and $\mathrm{D}$-glucose absorptions were, therefore, measured simultaneously, in vitro, in isolated jejunal mucosa of children. The results are as follows: 1) the steady-state accumulation of D-glucose (C/M glucose) is a function of the $\mathrm{Na}$ concentration gradient between cell and medium $(\mathrm{C} / \mathrm{M} \mathrm{Na})$. In Ringer solution, $\mathrm{C} / \mathrm{M}$ glucose $=3.97$ and $\mathrm{C} / \mathrm{M} \mathrm{Na}=0.29$; in the presence of $10^{-4} \mathrm{M}$ ouabain, $\mathrm{C} / \mathrm{M}$ glucose $=1.63$ and $\mathrm{C} / \mathrm{M} \mathrm{Na}$ $=0.60$, and in $\mathrm{Na}$ free solution, $\mathrm{C} / \mathrm{M}$ glucose $=0.99$. In the presence of phloridzin, $\mathrm{C} / \mathrm{M} \mathrm{Na}$ is not statistically different from that in Ringer, but $\mathrm{C} / \mathrm{M}$ glucose is significantly decreased. 2) The influx of D-glucose at the luminal membrane is a function of $\mathrm{Na}$ concentration in the bathing solution; it has the value of 4.41 $\mu \mathrm{mole} / \mathrm{hr} \mathrm{cm}^{2}$ in the presence of $\mathrm{Na}$ and of $1.65 \mu \mathrm{mole} / \mathrm{hr} \mathrm{cm}^{2}$ in absence of $\mathrm{Na}$. 3) The short-circuit current is a saturable function of D-glucose and of 3-O-D-methylglucose. The $K_{t}$ for glucose is 8.01 mM. These results support the concept of a coupling between $\mathrm{Na}$ and D-glucose absorptions at the luminal membrane of jejunal mucosa of children.
\end{abstract}

\section{Speculation}

These in vitro results might help to understand the stimulation of $\mathrm{Na}$ absorption by glucose in vivo. They might be useful in a physiologic approach of treatment of acute diarrhea in children.

The original formulation of the Na-gradient hypothesis (8) implied that the $\mathrm{Na}$ asymmetry between cell and surrounding could provide the energy required for the active $\mathrm{Na}$-dependent transport of glucose. The mechanism of the transport process would be a cotransport of $\mathrm{Na}$ and glucose at the luminal membrane. The hypothesis has received much support from experiments performed on animal intestine $(7,30)$; many experimental data may suggest that the hypothesis is indeed possible (9), while other data would rather suggest that it is incomplete $(2,15,20$, $31)$.

The Na-gradient hypothesis has been widely invoked to explain the dependence of glucose absorption on luminal $\mathrm{Na}$ concentration in the human intestine. For example, the hypothesis has been the physiologic basis of the treatment of diarrhea observed in cholera with oral administration of glucose containing solutions (25). Furthermore, the beneficial effect of such a treatment has often been considered as a proof of the validity of the $\mathrm{Na}$-gradient hypothesis in the human small intestine (13). However, there is little experimental evidence for the presence of such a process in the jejunum of children.

The present paper is concerned with the relationship between $\mathrm{Na}^{+}$and D-glucose transport in isolated jejunal mucosa of children. Biopsy specimens were used with the hope of developing a diagnostic method. The most conclusive experiments performed in in vitro animal preparations were repeated. The results indicate that 1) D-glucose intracellular accumulation is a function of the $\mathrm{Na}$ concentration gradient; 2) D-glucose influx at the luminal membrane is a function of external $\mathrm{Na}$ concentration; and 3) Dglucose stimulates transepithelial short-circuit current.

\section{METHODS}

For diagnostic purposes, per oral biopsies of jejunum were performed in 26 children, $77 \%$ of them between 6 months and 2 $\mathrm{yr}$ of age. In no instance was the biopsy performed on healthy children. Rather, histologic examination of the jejunum was prescribed by clinical observations. The project was accepted by The Committee on Ethics of the Department of Pediatrics of the University Paris VII. The procedure was as follows: after a 6-hr fast, jejunal tissue was obtained using a Carey capsule (5) positioned near the ligament of Treitz under fluoroscopic control. The criteria used to study the piece of jejunum was that the child had no diarrhea at the time of biopsy and that the jejunum was normal according to light microscopic criteria. In all cases, the biopsy specimen was divided into two parts, one for histology (diagnostic purpose) and one for transport studies. The only results presented are those obtained on jejunum with normal structure (Fig. 1): villous height greater than $350 \mu \mathrm{m}$ and the disaccharidase activities within normal range (12). With these conditions, clinical situations known to grossly alter intestinal $\mathrm{Na}$ transport were excluded. However, the children were sick (coeliac disease under gluten free diet, growth retardation, and pancreatic insufficiency) and the results may not be quantitatively regarded as normal.

Accumulation experiments $(12,14)$. The piece of jejunum that consisted of the epithelial layer was generally divided into two or three pieces of 3-10 mg each except if the original piece was too small. The tissue was then quickly placed in $10 \mathrm{ml}$ of appropriate buffer solution, incubated at $37^{\circ}$ and shaken throughout the 45 or $60 \mathrm{~min}$ of incubation period. The medium was bubbled with a humidified mixture of $95 \% \mathrm{O}_{2}$ and $5 \% \quad \mathrm{CO}_{2}$. Ringer solution contained (in mM) $140 \mathrm{Na}, 5.2 \mathrm{~K}, 1.2 \mathrm{Ca}, 1.2 \mathrm{Mg}, 120 \mathrm{Cl}, 25$ $\mathrm{HCO}_{3}, 2.4 \mathrm{HPO}_{4}$, and $0.4 \mathrm{H}_{2} \mathrm{PO}_{4}$. A Na-free solution was made by replacing all $\mathrm{NaCl}$ with choline chloride and $\mathrm{NaHCO}_{3}$ with $\mathrm{KHCO}_{3}$. The $\mathrm{Na}$ concentration of the solutions was measured by flame photometry. The initial $D$-glucose concentration was 10 $\mathrm{mM}$; it did not change throughout the incubation period.

In some experiments, $10^{-4} \mathrm{M}$ ouabain or $10^{-2} \mathrm{M}$ phloridzin was added to the bathing solution from the beginning of the experiment. The intracellular concentration of $\mathrm{D}$-glucose and of $\mathrm{Na}$ was always determined on the same piece of tissue by means of measurement of isotopic tracer: $2.5 \mu \mathrm{Ci}^{14} \mathrm{C}$ (U) D-glucose, $0.5 \mu \mathrm{Ci}$ ${ }^{22} \mathrm{Na}$ (Commisariat à l'Energie Atomique, Gif, France), and 12.5 $\mu \mathrm{Ci}{ }^{3} \mathrm{H}$ Inulin Methoxy (New England Nuclear) as extracellular marker $(21,24)$

At the end of the incubation period, the tissue was dipped in cold $0.3 \mathrm{M}$ mannitol, gently blottd, and weighed (wet wt). The 

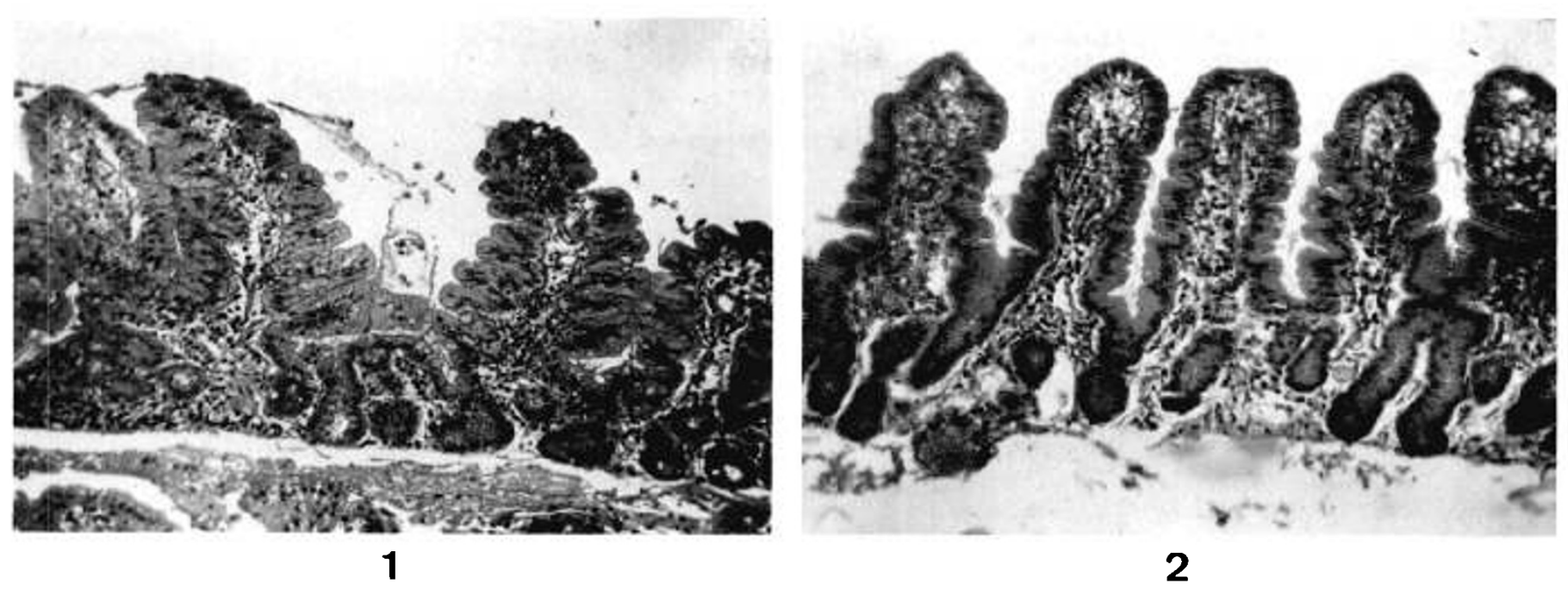

Fig. 1. Histologic appearance of a biopsy specimen before (1) and $90 \mathrm{~min}$ after (2) mounting in a Ussing chamber. Note that the epithelial structure is preserved.

tissue was then placed in $1 \mathrm{ml}$ of $0.1 \mathrm{~N}$ nitric acid for $24 \mathrm{hr}$ at room temperature in order to allow radioactivity extraction. The activity of the incubation D-glucose and $\mathrm{Na}$ were then calculated assuming an extracellular space equivalent to the inulin space and also, in these conditions, a negligible glucose metabolism. For example, $\mathrm{Na}$ concentration in the epithelial cells was calculated as:

$$
\begin{gathered}
{\left[{ }^{22} \mathrm{Na}\right]_{\mathrm{c}}=\left[(\mathrm{cpm})_{\mathrm{t}}^{\mathrm{Na}}-\mathrm{ECS} \cdot(\mathrm{cpm})_{\mathrm{m}}^{\mathrm{Na}}\right] / \mathrm{s} \cdot \mathrm{a} / \text { cell } \mathrm{H}_{2} \mathrm{O} \text { content }} \\
\mathrm{ECS}=(\mathrm{cpm})_{\mathrm{t}}^{\text {inulin }} /(\mathrm{cpm})_{\mathrm{m}}^{\text {inulin }} \\
\text { s.a. }=(\mathrm{cpm})_{\mathrm{m}}^{\mathrm{Na}} /[\mathrm{Na}]_{\mathrm{m}}
\end{gathered}
$$

in which $(\mathrm{cpm})_{t}{ }^{\mathrm{Na}}$ and $(\mathrm{cpm})_{t}{ }^{\text {inulin }}$ are the total counts $/ \mathrm{min}$, of ${ }^{22} \mathrm{Na}$ and ${ }^{3} \mathrm{H}$ inulin in the tissue, respectively, ECS is the extracellular space measured by ${ }^{3} \mathrm{H}$ inulin, $\left(\mathrm{cpm}_{\mathrm{m}}\right)^{\mathrm{Na}}$ and $(\mathrm{cpm})_{\mathrm{m}}{ }^{\text {inulin }}$ are the cpm of ${ }^{22} \mathrm{Na}$ and ${ }^{3} \mathrm{H}$ inulin/unit volume, respectively. S.A. is the specific activity of ${ }^{22} \mathrm{Na}$ in the medium, and the cell $\mathrm{H}_{2} \mathrm{O}$ content is obtained by subtraction of the dry wt and ECS from the wet wt of the tissue.

Influx experiments. The experimental procedures for determining glucose flux from incubation solution to cell, across the brush border membrane, were similar to those used by Schultz et al. (32) in rabbit ileum.A piece of jejunum was mounted, luminal surface up, on a moistened filter paper which rested on a piece of lucite; the serosal side was not exposed to the mucosal solution. The block was then covered by a thin $(1 \mathrm{~mm})$ plate of lucite with an aperture of $4 \mathrm{~mm}$ diameter; through this hole, the mucosal surface was directly in contact with the mucosal solution. After mounting the tissue, the whole block was dipped in $10 \mathrm{ml}$ Ringer plus 10 $\mathrm{mM}$ D-glucose at $37^{\circ}$, bubbled with $95 \% \mathrm{O}_{2}$ and $5 \% \mathrm{CO}_{2}$, and regularly shaken. After $30 \mathrm{~min}$ of preincubation, the block was dipped in the incubation solution which contained either the same Ringer with $10 \mathrm{mM}$ D-glucose, $2.5 \mu \mathrm{Ci}{ }^{14} \mathrm{C}(\mathrm{U}) \mathrm{D}$-glucose and 37.5 $\mu \mathrm{Ci}^{3} \mathrm{H}$ inulin methoxy or the $\mathrm{Na}$-free solution with $10 \mathrm{mM}$ Dglucose, $2.5 \mu \mathrm{Ci}{ }^{14} \mathrm{C}$ D-glucose and $37.5 \mu \mathrm{Ci}^{3} \mathrm{H}$ inulin methoxy. For the $\mathrm{Na}$-free incubation the block was rinsed $3 \mathrm{~min}$ in $\mathrm{Na}$-free solution with $10 \mathrm{mM}$ glucose without isotopes before isotopic incubation in order to remove $\mathrm{Na}$ from the mucosal surface of the tissue. The incubation period was approximately $60 \mathrm{sec}$. The tissue was then dipped in cold $0.3 \mathrm{M}$ mannitol, gently blotted, and extracted for $24 \mathrm{hr}$ in $0.1 \mathrm{~N}$ nitric acid. The activity of the incubation and of the tissue extract was counted and the D-glucose uptake was calculated, after correction for the inulin space for each piece of tissue.

Measurement of short-circuit current, Isc. The experimental procedures for determining the variations of Isc as a function of D-
Table 1. D -glucose cell/incubation solution concentration ratios. All tissues were incubated for $45-60 \mathrm{~min}$ in the presence of $10 \mathrm{mM}$ D-glucose. Comparison with control (Ringer's) solution are indicated by the P values; all the 4 situations are significantly different at the $P<0.01$ level.

\begin{tabular}{lcccc}
\hline & \multicolumn{3}{c}{ Incubation solution } \\
\cline { 2 - 5 } & & $\begin{array}{c}\text { Ringer's } \\
+ \\
10^{-4} \mathrm{M} \\
\text { ouabain }\end{array}$ & Na-free & $\begin{array}{c}\text { Ringer's } \\
+ \\
10^{-2} \mathrm{M} \\
\text { phloridzin }\end{array}$ \\
\hline$\overline{\mathrm{X}}$ & Ringer's & 1.63 & 0.99 & 2.99 \\
SEM & 3.97 & 0.35 & 0.18 & 0.21 \\
$N$ & 0.23 & 7 & 11 & 7 \\
$P$ & 23 & $<0.01$ & $<0.001$ & $<0.01$ \\
\hline
\end{tabular}

glucose concentration in the bathing solution were that described by Schultz and Zalusky (34) for rabbit ileum. The biopsy specimen (Fig. 1) was mounted on a filter paper as a flat sheet between two lucite chambers containing Ringer's solution. The exposed area was $12.57 \mathrm{~mm}^{2}$. The solution was circulated, oxygenated, and maintained at $37^{\circ}$. The thermostated reservoirs contained $1 \mathrm{ml}$ of solution on each side. The special chambers described by Rhode and Andersen (28) were not used. The mucosal and serosal solutions were connected via agar bridges to calomel electrodes for measurement of transepithelial potential difference (PD) and to $\mathrm{Ag}-\mathrm{AgCl}$ electrodes for passing current through the system. The current required to maintain a particular PD across the tissue was supplied by an automatic voltage clamp (29) that made the appropriate correction for the fluid resistance between the PD sensing bridges. Isc was recorded in the absence of PD. The conductance, $G$, was calculated as the slope of $I$ as a function of $P D$ between -3 and $+3 \mathrm{mV}$ because, in this range of $P D, G$ was constant.

\section{RESULTS}

Intracellular accumulation of $D$-glucose. The first row in Table 1 shows the mean $( \pm$ SEM) D-glucose intracellular to extracellular concentration ratio determined on 23 pieces of juvenile jejunum incubated for 45-60 min in Ringer's solution containing $10 \mathrm{mM}$ D-glucose. In all samples of jejunum, the ratio was greater than unity. These observations are in good agreement with the 4.5 accumulation ratio found by Elsas et al. (14) for $10 \mathrm{mM}$ D-glucose in jejunum of human adults. 
The conclusion that D-glucose accumulation by intestinal epithelium of children is an active process involves the assumption that tissue ${ }^{14} \mathrm{C}$ content is a valid measurement of $\mathrm{D}$-glucose content. Radiochromatography of the tissue extracts and of the bathing solution at the end of the incubation period was unable to detect significant metabolism of ${ }^{14} \mathrm{C} \mathrm{D}$-glucose. Furthermore, with chemical analysis (glucose oxidase), it was found that the rate of intracellular catabolism of ${ }^{14} \mathrm{C}$ glucose by jejunal epithelium in Ringer is much smaller than the rate of glucose transport (and in fact could not be detected). The ratio of the glucose specific activity $\left({ }^{14} \mathrm{C} \mathrm{DPM} /\right.$ glucose concentration determined by glucose oxidase) in medium over tissue extract was 1.02 .

Table 1 also shows the D-glucose concentration ratio of seven pieces of jejunum incubated in glucose ringer solution containing $10^{-4} \mathrm{M}$ ouabain. The accumulation is drastically reduced $(P<$ 0.01 ), although not entirely abolished. The accumulation is further decreased in $\mathrm{Na}$-free solution and in fact entirely abolished. There is no overlap between the values obtained in control and in $\mathrm{Na}$ free solutions. These results are also in agreemeent with results on adult human jejunum (14) where ouabain produced a $85 \%$ inhibition and $\mathrm{Na}$-free solution a $90 \%$ inhibition of D-glucose accumulation. These observations suggest that the overall D-glucose intracellular accumulation is $\mathrm{Na}$-dependent. Finally, Table 1 shows a decreased $(P<0.01)$ glucose accumulation in the presence of phloridzin, although it is not entirely abolished. In each of the seven pieces of tissue, the glucose concentration ratio is greater than unity.

Intracellular $\mathrm{Na}$ concentration. In many experiments, intracellular $\mathrm{Na}$ and glucose concentrations were determined simultaneously on the same piece of jejunum. The results of $\mathrm{Na}$ intracellular to extracellular concentration ratio appear in Table 2. After 45-60 min in Ringer solution, the intracellular $\mathrm{Na}$ concentration has a value of $41 \mathrm{mM}$; this value is significantly lower $(P<0.001)$ than the $140 \mathrm{mM} \mathrm{Na}$ concentration in the incubation solution.

It is generally accepted that the low intracellular $\mathrm{Na}$ concentration is related, at least in part, to the ouabain sensitive, $\mathrm{Na}, \mathrm{K}$ activated ATPase. The effect of $10^{-4} \mathrm{M}$ ouabain added to the glucose-Ringer solution appears in Table 2. The intracellular $\mathrm{Na}$ concentration is significantly higher $(P<0.02)$ in the presence of ouabain $(84 \mathrm{mM})$ than in control situation $(41 \mathrm{mM})$. It is however lower than the $140 \mathrm{mM} \mathrm{Na}$ of the external Ringer solution. The reason for this relatively low intracellular $\mathrm{Na}$ concentration is not clear. It might be related to the duration of the incubation period. Indeed, the time course of the inhibition of Isc by ouabain indicates that in most tissues the Isc has a small, but finite value at $45 \mathrm{~min}$. It is generally entirely abolished after $60 \mathrm{~min}$. Similarly, in rabbit ileum $(10)$ in presence of ouabain, the intracellular $\mathrm{Na}$ concentration reaches the extracellular $\mathrm{Na}$ concentration between 45-60 min. Alternatively, ouabain may not inhibit the overall process of pumping $\mathrm{Na}$ out of the cell. Such a process has already been described in the epithelium of the proximal tubule of the kidney (27).

The ${ }^{22} \mathrm{Na}$ ratio of 1.31 , found at the end of the incubation in "Na-free solution," indicates that there was no intracellular exchangeable $\mathrm{Na}$ left after $45-60 \mathrm{~min}$. This value is not significantly different from unity. Because the nonexchangeable $\mathrm{Na}$ pool at

Table 2. Na cell/incubation solution concentration ratios. Na and $\mathrm{D}$-glucose concentrations were determined in the same piece of tissue

\begin{tabular}{|c|c|c|c|c|}
\hline & \multicolumn{4}{|c|}{ Incubation solution } \\
\hline & Ringer's & $\begin{array}{c}\text { Ringer's } \\
+ \\
10^{-4} \mathrm{M} \\
\text { ouabain }\end{array}$ & Na-free & $\begin{array}{c}\text { Ringer's } \\
+ \\
10^{-2} \mathrm{M} \\
\text { phloridzin }\end{array}$ \\
\hline$\overline{\mathrm{X}}$ & 0.29 & 0.60 & 1.31 & 0.28 \\
\hline SEM & 0.04 & 0.14 & 0.31 & 0.07 \\
\hline$N$ & 22 & 6 & 9 & 7 \\
\hline$P$ & & $<0.02$ & $<0.01$ & NS \\
\hline
\end{tabular}

any intracellular $\mathrm{Na}$ concentration in rabbit ileum represents only $10 \%$ of the total $\mathrm{Na}$ pool (37), it is reasonable to assume that there was no significant $\mathrm{Na}$ concentration gradient in that situation.

Finally, in presence of phloridzin, the $\mathrm{Na}$ concentration ratio was not statistically different from that measured in control situation. This finding suggests that the phloridzin inhibitory effect on glucose accumulation is not related to a $\mathrm{Na}$ effect, but rather to a direct inhibitory effect on glucose transport at the brush border membrane (8). The permanence of a $\mathrm{Na}$ concentration gradient suggests that phloridzin in high concentration does not drastically impair cellular metabolism in these conditions.

Effect of Na on D-glucose influx. Preliminary experiments were carried out on rabbit ileum to assess the validity of the method and particularly our ability to measure influx with a $12.57 \mathrm{~mm}^{2}$ of tissue exposed. The time course of the movement of D-glucose from the mucosal solution into the epithelial layer of stripped rabbit ileum was examined. Figure 2 shows the uptake of glucose from $20-80 \mathrm{sec}$; each point represents one determination and all points were obtained using tissue from one animal. This experiment was repeated several times; in all experiments the uptake of D-glucose is linear over the entire 80 -sec interval. As previously discussed by Schultz et al. (32), this observation indicates that there is no significant backflux of tracer from the tissue to the mucosal solution; therefore, the measure of the ${ }^{14} \mathrm{C}$ D-glucose tissue uptake during this brief period provides an appropriate estimate of influx.

The present experiments were designed to study the effect on D-glucose influx of changes in $\mathrm{Na}$ concentration in the mucosal solutions at constant $\mathrm{Na}$ concentration in the epithelial cell. The results of these studies appear in Table 3. D-Glucose influx was markedly depressed by complete removal of $\mathrm{Na}$ from the external solution.

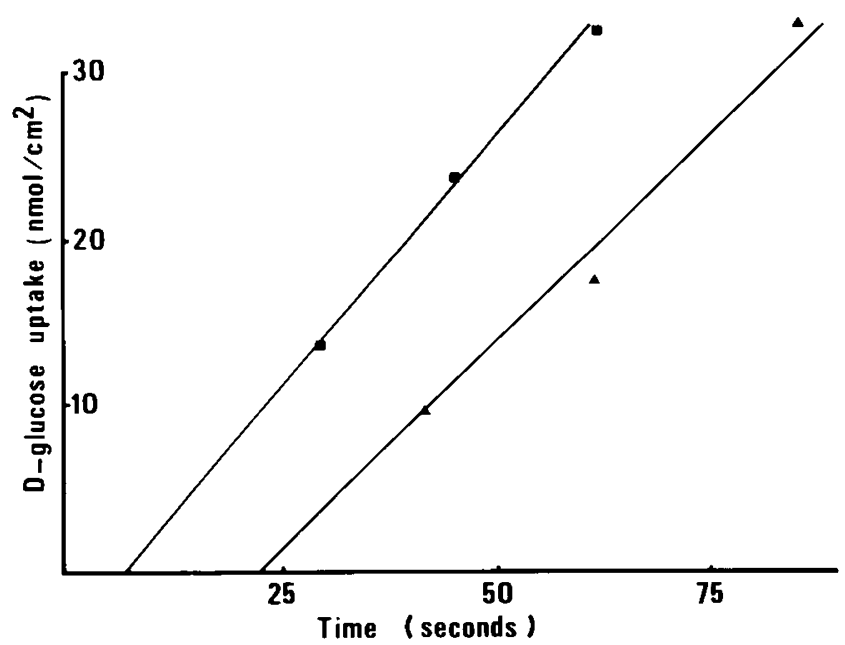

Fig. 2. D-glucose uptake across the brush border membrane as a function of time. Each line represents the regression line calculated from the results obtained in one intestine of rabbit.

Table 3. Effect of external Na concentration on D-glucose influx $\left(\mu \mathrm{mole} / \mathrm{hr} \mathrm{cm}^{2}\right)$. D-glucose concentration in incubation solution is $10 \mathrm{mM}$.

Preincubation solution

\begin{tabular}{lcc}
\hline \multicolumn{2}{c}{ Preincubation solution } \\
& $\mathrm{Na}=140 \mathrm{mM}$ & $\mathrm{Na}=140 \mathrm{mM}$ \\
\cline { 2 - 3 } & \multicolumn{2}{c}{ Incubation solution } \\
& $\mathrm{Na}=140 \mathrm{mM}$ & $\mathrm{Na}=0 \mathrm{mM}$ \\
\hline$\overline{\mathrm{X}}$ & 4.41 & 1.65 \\
$\mathrm{SEM}$ & 0.68 & 0.19 \\
$N$ & 5 & 6 \\
$P$ & & $<0.01$ \\
\hline
\end{tabular}


Table 4. Total tissue conductance (in $\mathrm{mmho} / \mathrm{cm}^{2}$ ) in stripped rabbit ileum mounted in Ussing chambers of different diameters

\begin{tabular}{lccc}
\hline & \multicolumn{3}{c}{ Exposed serosal area $\left(\mathrm{cm}^{2}\right)$} \\
\cline { 2 - 4 } & 0.1257 & 1.13 & 3.14 \\
\hline$\overline{\mathrm{X}}$ & 23.74 & 24.92 & 22.15 \\
SEM & 3.02 & 1.74 & 1.79 \\
$N$ & 13 & 18 & 17 \\
\hline
\end{tabular}

Table 5. Effect of D-glucose ( $30 \mathrm{mM}$ ) on transepithelial electrical parameters. Number of jejunal biopsy specimens $=I 1$

\begin{tabular}{|c|c|c|c|c|}
\hline & & $\begin{array}{c}\text { PD } \\
(\mathrm{mV})\end{array}$ & $\begin{array}{c}\text { Isc } \\
\left(\mu \mathrm{Eq} / \mathrm{hr} \mathrm{cm}^{2}\right)\end{array}$ & $\begin{array}{c}\mathrm{G} \\
\left(\mathrm{mmho} / \mathrm{cm}^{2}\right)\end{array}$ \\
\hline \multirow[t]{2}{*}{ Ringer } & $\overline{\mathrm{x}}$ & 1.92 & 2.00 & 26.65 \\
\hline & SEM & 0.20 & 0.37 & 3.38 \\
\hline \multirow{2}{*}{$\begin{array}{l}\text { Ringer } \\
+ \\
\text { D-glucose }\end{array}$} & $\overline{\mathrm{X}}$ & $3.10^{1}$ & $3.72^{1}$ & $32.22^{2}$ \\
\hline & SEM & 0.31 & 0.54 & 3.59 \\
\hline
\end{tabular}

However, the value of glucose influx in the absence of $\mathrm{Na}$ was significantly greater than zero.

Effect of D-glucose on transepithelial electrical parameters (Table 4). In all the 16 pieces of jejunum studied, the transmural PD was oriented with the serosal solution positive relative to the mucosal solution. Fifteen min after mounting in Ringer's solution the tissue PD values average $1.94( \pm 0.23) \mathrm{mV}$, the Mean $\mathrm{I}_{\mathrm{sc}}$ was 7.53 ( \pm 1.05) $\mu \mathrm{A} / 0.1257 \mathrm{~cm}^{2}$, and the mean G was 28.98 ( \pm 2.95$) \mathrm{mmho} /$ $\mathrm{cm}^{2}$. All these parameters remained stable throughout the experiments (up to $90 \mathrm{~min}$ ) although no experiment was specifically designed to study the change in these values with time.

The present results are in agreement with data obtained in Ussing-type chambers in biopsies of jejunal mucosa from adults after recovery from cholera (28), in surgical specimens of human jejunum (4), and of human ileum $(1,18)$, in human fetal small intestine (22), and also in animal small intestine (33).

The possible involvement of methodology in determining transepithelial electrical parameters was further examined because they are central to the discussion of the mechanism of glucose and $\mathrm{Na}$ transport in jejunum of children. The importance of edge damage was specifically examined in relation with the small surface exposed $\left(12.57 \mathrm{~mm}^{2}\right)$ by measurement of $G$ on adjacent pieces of rabbit ileum (stripped of its muscular layer) mounted in Ussing chambers of $3.14 \mathrm{~cm}^{2}, 1.13 \mathrm{~cm}^{2}$, and $0.1257 \mathrm{~cm}^{2}$. The results obtained on 13 rabbits (Table 4) indicate that there is no statistical difference in $G$ with changes in exposed surface area. Similarly, differences could not be found in the other electrical measurements and on the kinetic parameters.

The histologic structure of the tissue was also considered. In 50 consecutive jejunal biopsy specimens there was no muscular tissue; the muscularis mucosa was present in only two specimens. The bottom of the crypts was always present and there was no microscopic evidence of a hole of any sort. The comparison of light microscopic appearance of the jejunum before and after $90 \mathrm{~min}$ in the Ussing chamber indicates no important change in the epithelial structure (Fig. 1).

The addition of $30 \mathrm{mM}$ D-glucose on both sides of the tissue caused a significant increase in PD, $I_{s c}$, and $G$ (Table 5). In all jejunum studied we observed an increase in $I_{9 c}$. The time course of the phenomenon was not constant and was probably dependent upon the rate of diffusion of glucose in the bathing solution. The $\Delta I_{\mathrm{Bc}}$ was apparent within sec after addition of glucose suggesting a role for external glucose in $\mathrm{Na}$ transport (Fig. 3). Similar results were found with $3 \mathrm{O}$-methyl glucose in rabbit ileum (34). Exper-

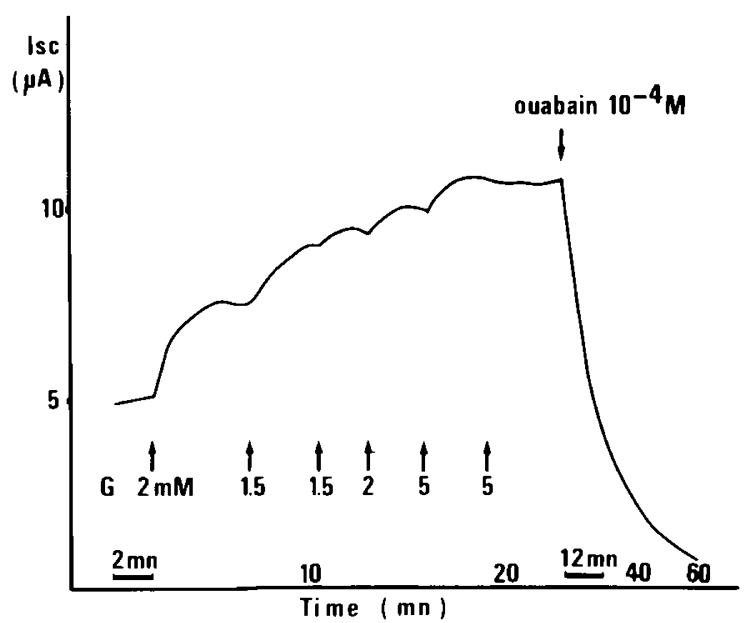

Fig. 3. Effect of D-glucose on short-circuit current, $I_{s c}$. The tissue was placed in an Ussing chamber with Ringer on both sides. Firstly, $2 \mathrm{mM}$ of glucose, G, was added on both sides of the tissue, then at intervals (indicated by arrows) $1.5,1.5,2,5$, and $5 \mathrm{mM}$ were added to reach a final concentration of $17 \mathrm{mM}$ of glucose. After a plateau was reached, $10^{-4} \mathrm{M}$ ouabain was added. Drawing from the original recording.

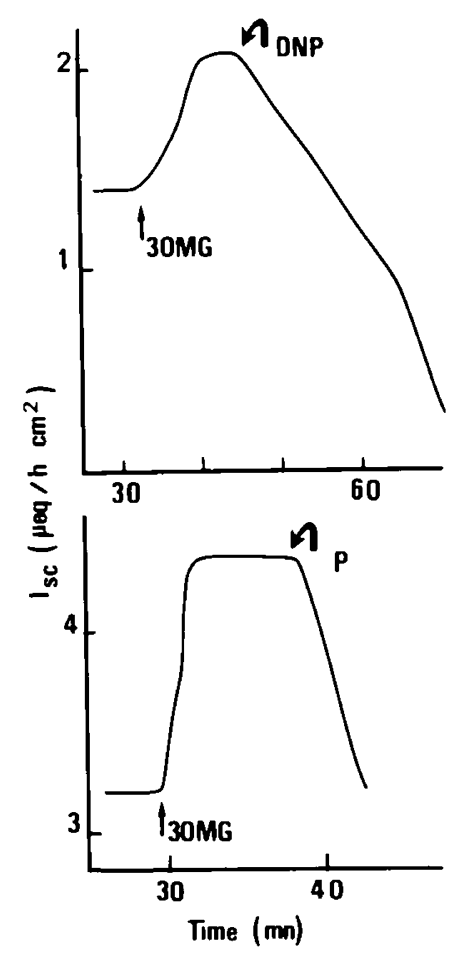

Fig. 4. Effect of dinitrophenol, DNP, and phloridzin, P, on short-circuit current, $I_{\mathrm{s}}$. After a steady state was reached in Ringer solution, $30 \mathrm{mM} \mathrm{3-}$ 0 -methyglucose, was added on both sides of the tissue. At the arrow, either dinitrophenol or phloridzin was added.

iments were, therefore, designed to study the effect of external glucose and metabolism on $\Delta I_{\mathrm{sc}}$. Figure 4 indicates that $3 \mathrm{O}$-Dmethylglucose, which is actively transported but not metabolized in animals (7) produced a rapid rise in the $I_{s c}$. The addition of $10^{-2} \mathrm{M}$ phloridzin which is a competitive inhibitor for the binding of D-glucose at the brush border membrane in human (21) resulted in an immediate decline in the $I_{s c}$. In all experiments $10^{-4} \mathrm{M}$ ouabain (added on both sides of the tissue) resulted in a progressive decline in $I_{s c}$. A similar effect was observed in tissues incubated in the presence or in absence of sugars. Finally, the addition 


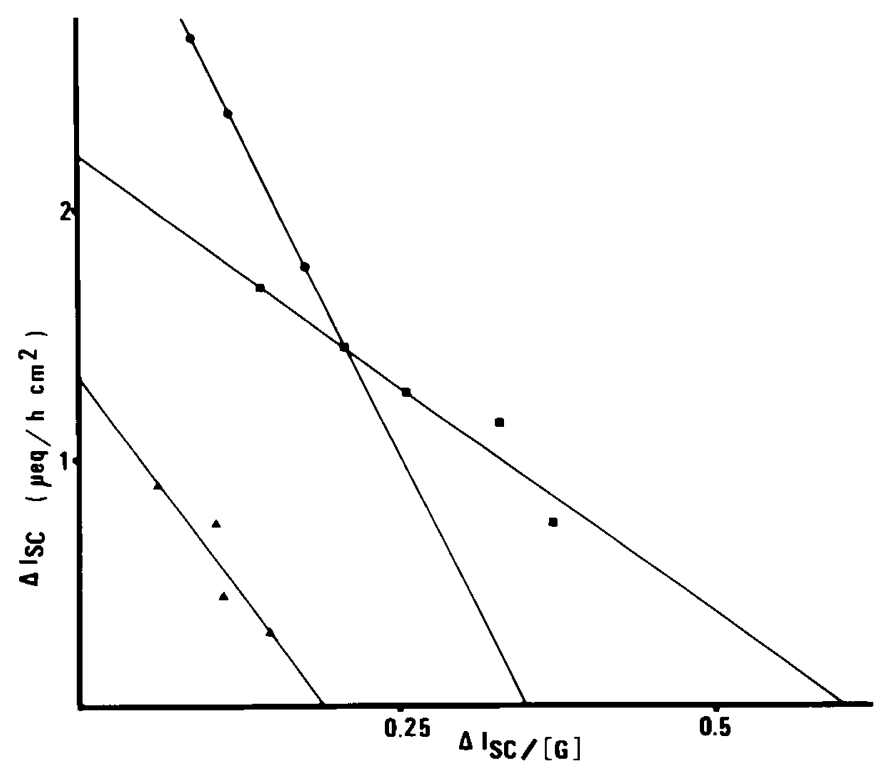

Fig. 5. Eadie-Hofstee plot of the stimulation of short-circuit ( $\Delta \mathrm{Isc})$ in the presence of increasing glucose concentration $[G]$ in the bathing solution. Each line represents the results obtained on one piece of jejunum. In this plot, the value of the intercept on the $y$ axis represents the maximal increase in short-circuit current and the slope in equal to $-\mathrm{K}_{\mathrm{t}}$.

of $10^{-4} \mathrm{M}$ dinitrophenol also resulted in a complete disappearance of $I_{\mathrm{gc}}$.

In a second group of experiments, $\Delta I_{s c}$ was studied as a function of D-glucose in the bathing solution. It appears (Fig. 3 and Fig. 5) that $I_{\mathrm{sc}}$ is a saturable function of D-glucose and 3-O-methylglucose concentrations in the bathing solution. Kinetic analysis suggests that the stimulation of $I_{\mathrm{sc}}$ could be described as a single transport process having a maximal increase in $I_{\mathrm{sc}}$ of $2.54 \pm 0.39 \mu \mathrm{eq} / \mathrm{hr}$ $\mathrm{cm}^{2}$ (mean \pm SEM of 6 experiments) and a D-glucose concentration which results in half maximal $\Delta \mathrm{I}_{\mathrm{sc}}, \mathrm{K}_{\mathrm{t}_{1, * c}} 8.01 \pm 1.14 \mathrm{mM}$.

Due to technical reasons the $\mathrm{K}_{\mathrm{t}_{\text {Ir. }}}$ may have been slightly over estimated. In the first experiments, the $\Delta$ Isc plateau was not exactly determined because the Isc values were not paper recorded but read by sight. As shown in Figure 3, it is difficult to determine the exact increment in Isc for each glucose concentration in the bathing solution, and the unstirred water layer may play a significant role.

\section{DISCUSSION}

Some hypotheses are so tempting, they are easily accepted even before experiments prove them to be right. This is the case with the Na-gradient hypothesis (8). This hypothesis is accepted and used in pediatric gastroenterology while it is still under investigation by animal physiologists. Some experimental data suggest a $\mathrm{Na}$-dependence for the glucose absorption and a glucose-dependence for the $\mathrm{Na}$ absorption in the jejunum of children (13). However, no study has been specifically designed to test the possibility of a cotransport between $\mathrm{D}$-glucose and $\mathrm{Na}$ in such an epithelium; the reason why could be the technical difficulty in measuring or in controlling the driving forces acting on glucose and $\mathrm{Na}$ transport.

The results of our studies can be summarized as follows: 1) the steady-state accumulation of D-glucose in epithelial cells is a function of the $\mathrm{Na}$ concentration gradient between cell and medium; 2) the influx of D-glucose at the luminal membrane is a function of $\mathrm{Na}$ concentration in the bathing solution at fixed intracellular $\mathrm{Na}$ concentration; 3) the short-circuit current is a saturable function of D-glucose and 3-O-D-methylglucose concentrations in the bathing solution. These results present great simi- larities between the Na-glucose transport system in the pediatric jejunum and the animal intestine. These results support the concept of a sodium and D-glucose cotransport at the luminal membrane of jejunual epithelium in children.

The validity of the conclusions suggested in this paper strongly depends on the reliability of the in vitro investigation. Each of the three methods used need critical study. In the steady-state accumulation experiments, the intracellular glucose accumulation and the potential energy supplied for this accumulation by the $\mathrm{Na}$ concentration gradient were simultaneously measured. Here, three methodologic difficulties have been met. At first, the measurements depend on the determination of the intracellular volume that, in turn, depends on the determination of the extracellular volume. For this measurement, ${ }^{3} \mathrm{H}$ inulin has been used for a long time on human $(12,14)$ and on animal intestine $(32,35)$. Its validity has been recently reassessed in rabbit ileum (24). The high molecular weight of inulin, 5000 daltons, could, however, lead to an underestimation of the extracellular space. This would also underestimate the intracellular glucose concentration (if the glucose concentration ratio is greater than unity). This difficulty, however, cannot account for the different results observed in different experimental conditions. The second possibility for error could be the use of ${ }^{14} \mathrm{C}$ counts to measure the intracellular glucose concentration; in fact, it has been found that the glucose specific activity in the tissue extract equal to that of the extracellular glucose; similar results were obtained previously on human jejunal biopsies (14). The absence of glucose metabolism in this situation is somewhat different from what has been found in animal intestine. However, it is well demonstrated that glucose metabolism may change significantly with different species and different experimental conditions (8). The third methodologic difficulty deals with the $\mathrm{Na}$ measurement. The determination of the intracellular ${ }^{22} \mathrm{Na}$ is certainly a precise measure of the exchangeable $\mathrm{Na}$ pool; about $90 \%$ of the total $\mathrm{Na}$ pool (37). The energy necessary for the intracellular glucose accumulation of 3.97 (Table 1) over the extracellular glucose can be estimated:

$$
\begin{array}{r}
\mathrm{E}=\mathrm{RT} \text { Ln glucose intracellular /glucose extracellular } \\
=949 \mathrm{cal} / \mathrm{mole}
\end{array}
$$

Using the results found in bullfrog intestine (3) and in rabbit ileum (30) one can estimate the energy of the $\mathrm{Na}$ electrochemical potential when the $\mathrm{Na}$ concentration gradient measured in pediatric jejunum is found to be 0.29 :

$$
\begin{aligned}
& \mathrm{E}=\mathrm{RT} \operatorname{Ln}[\mathrm{Na}] \text { extracellular } / \gamma[\mathrm{Na}] \\
& \text { intracellular }+\mathrm{ZF} \psi_{\mathrm{mc}}=2112 \mathrm{cal} / \text { equiv }
\end{aligned}
$$

Where $\gamma$ is the activity coefficient of $0.5, \psi_{\mathrm{mc}}$ is the transmembrane PD $(-40 \mathrm{mV})$ and $R, F, Z$, and $T$ have their usual meaning.

These results indicate that if there is D-glucose-Na cotransport, the energy of the $\mathrm{Na}$ electrochemical potential is, in principle, sufficient to accumulate glucose in the cell from glucose in Ringer solution. The coupling efficiency would be of about 0.4 , which is very close to that measured in bullfrog intestine for galactose (3).

The location of the glucose- $\mathrm{Na}$ interaction appears to be at the luminal membrane. Indeed, many experimental results obtained in animal intestine indicate that the apparent active step (i.e., against a concentration gradient) in glucose transport takes place at this membrane. The inhibition by phloridzin (Table 2) suggests the same thing happens in the jejunum of children; especially because autoradiography has provided direct evidence that phloridzin is a competitive inhibitor of galactose at the brush border membrane of human jejunum (21). Furthermore, phloridzin decreases the short-circuit current after stimulation with 3-o-D-methylglucose (Fig. 4). Recently, Lücke et al. (23) obtained direct evidence for a cotransport of glucose and $\mathrm{Na}$ by brush border membrane vesicles isolated from human small intestine.

It was then important to look for the effect of $\mathrm{Na}$ concentration on the glucose flux across the luminal membrane. The measurement of unidirectional glucose influx has certain methodologic 
difficulties. Of them, two will be discussed here. The first one deals with the validity of the measured influx. For if there is an unstirred water layer on the surface of the luminal membrane, a 1-min incubation period may be too short to measure the real entry of glucose into the cell. The measurements of efflux in jejunal mucosa of tortoise (16) and in rabbit ileum (35) suggest that the unstirred water layer can indeed be important. However, the measurement of glucose accumulation as a function of time presented in Figure 2 suggests a very small diffusional space. The regression line of glucose accumulation as a function of time extrapolated to zero accumulation crosses the time axis at approximately $10 \mathrm{sec}$. This might suggest that the luminal diffusional space is small. This conclusion would be in agreement with the results of Preston et al. (26). Even if in our experimental conditions there is a small unstirred water layer, its existence cannot account for the decrease of the glucose influx in absence of $\mathrm{Na}$.

The second methodologic difficulty is the following: according to the Na-gradient hypothesis active glucose accumulation should no longer be possible in absence of a Na-gradient (30). The inhibition of net transport against a concentration difference should be primarily the result of identical unidirectional glucose flux in and out of the cell; the glucose influx would be primarily dependent on the extracellular $\mathrm{Na}$ concentration and the glucose efflux would be primarily dependent on the intracellular $\mathrm{Na}$ concentration (30). The measurements taken in jejunum of children show that the glucose influx is indeed strongly dependent on the $\mathrm{Na}$ concentration in the extracellular solution at constant intracellular $\mathrm{Na}$ concentration. However, the measurement of glucose efflux as a function of intracellular $\mathrm{Na}$ concentration is not yet available in this tissue. In rabbit ileum, Curran et al. (10) were able to demonstrate that $\mathrm{L}$-alanine transport across the brush border membrane is a reversible system for both the influx and the efflux of alanine dependent on the local concentration of $\mathrm{Na}$.

Measurements of the short-circuit current, $I_{s c}$, were used to look for the action of D-glucose on $\mathrm{Na}$ absorption when D-glucose was added in the bathing solutions. The reason for this choice has to be explained. The variations of $I_{\mathrm{sc}}$ seem to represent the increase of $\mathrm{Na}$ absorption in the present conditions. A parallel increase of $J_{\text {net }}^{\mathrm{Na}}$ and $I_{s c}$ after addition of glucose has been measured previously in surgical pieces of human jejunum $(4,6)$ and ileum $(6)$ and in a very meticulous study in pieces of adult jejunal biopsies (28). These results would therefore suggest that the D-glucose stimulated $I_{s c}$ in jejunum of children would also represent increased $\mathrm{Na}$ absorption.

They do not, however, point out the mechanism of this stimulation. This phenomenon is inhibited by ouabain and dinitrophenol; yet the metabolic energy does not have to be directly coupled to the transport phenomenon at the brush border membrane. Indeed, D-glucose and 3-O-D-methyl glucose stimulate $\mathrm{I}_{\mathrm{sc}}$, but they are not metabolized in these experimental conditions. Similar results were originally observed in rabbit ileum (34). Thus, it appears that in jejunum of children the D-glucose- $\mathrm{Na}$ interaction is situated at the brush border membrane. Kinetic studies could further suggest that $\mathrm{D}$-glucose and $\mathrm{Na}$ share a common transport system. The glucose concentration producing a half maximal rate of glucose transport $\left(\mathrm{K}_{\mathrm{t}_{\mathrm{i}}}\right)$ was $4.2 \mathrm{mM}$ in pieces of human jejunum (14) and above $5 \mathrm{mM}$ in isolated brush border membrane vesicles (23). In the present experiments, the glucose concentration producing a half maximal increase in $I_{9 c}\left(K_{t_{1 / c}}\right)$ has a mean value of $8 \mathrm{mM}$ with a range value between 3.7 and $11.9 \mathrm{mM}$. As discussed in Results the $\mathrm{K}_{\mathrm{t}_{\mathrm{l} e}}$ value is probably slightly overestimated. These results could suggest that $\mathbf{K}_{t_{\text {lac }}}$ and $K_{t_{G}}$ are two measures of the same phenomenon; $\mathbf{K}_{t_{\text {lex }}}$ and $K_{t_{G}}$ would be the Michaelis constant of D-glucose- $\mathrm{Na}$ cotransport system.

\section{REFERENCES AND NOTES}

1. Al-Awqati.Q..Cameron, J. L. and Greenough III, W. B.: Electrolyte transport in human ileum: effect of purified cholera exotoxin. Am. J. Physiol., 224: 818 (1973)

2. Alvarado, F.: Sodium-driven transport. A re-evaluation of the Sodium-Gradient
Hypothesis. In: J. W. L. Robinson: Intestinal Ion Transport, pp. 117-152 (M. T. P. Press Ltd., Lancaster, U.K. 1976).

3. Armstrong, W. McD., Byrd, B. J., and Hamang, P. H.: The $\mathrm{Na}^{+}$gradient and Dgalactose accumulation in epithelial cells of bullfrog small intestine. Biochim. Biophys. Acta, 330: 237 (1973).

4. Binder, H. J.: Sodium transport across isolated human jejunum. Gastroenterology, 67: 231 (1974).

5. Carey Jr., J. B.: A simplified gastrointestinal biopsy capsule. Gastroenterology, 46: $550(1964)$

6. Corbett, C. L., Isaacs, P. E. T., Riley, A. K., and Turnberg, L. A.: Human intestinal ion transport in vitro. Gut, 18: 136 (1977).

7. Crane, R. K.: Absorption of sugars. In: Handbook of Physiology, Section 6, Vol III, Intestinal absorption. pp 1323-1353 (American Physiological Society, The Williams \& Wilkins Company, Baltimore, 1968).

8. Crane, R. K.: Hypothesis for mechanism of intestinal active transport of sugars. Fed. Proc., 2I: 891 (1962).

9. Crane, R. K., Malathi, P., and Preiser, H.: Reconstitution of specific $\mathrm{Na}^{+}$ dependent $\mathrm{D}$-glucose transport in liposomes by Triton $\mathrm{X}-100$ extracted proteins from purified brush border membranes of hamster small intestine. Biochem. Biophys. Res. Commun. 71: 1010 (1976)

10. Curran, P. F., Hajjar, J. J., and Glynn, I. M.: The sodium-alanine interaction in rabbit ileum. Effect of alaninine on sodium fluxes. Gen. Physiol., 55: 297 (1970).

11. Desjeux, J. F.: Possible coupling between $\mathrm{Na}^{+}$and D-glucose absorption in normal jejunal mucosa of children. In: J. W. L. Robinson: Intestinal Ion Transport, pp 376-378 (M. T. P. Press Ltd., Lancaster U.K., 1976).

12. Desjeux. J. F., Sassier, P., Tichet, J., Sarrut, S., and Lestradet, H.: Sugar absorption by flat jejunal mucosa. Acta Paediatr. Scand., 62: 531 (1973).

13. Desjeux. J. F., Tannenbaum, C., Tai, Y. H., and Curran, P. F.: Effects of sugars and amino acids on Na movement across small intestine. Am. J. Dis. Child. 131: 331 (1977)

14. Elsas, L. J., Hillman, R. E., Patterson, J. H., and Rosenberg, L. E.: Renal and intestinal hexose transport in familial glucose-galactose malabsorption. J. Clin. Invest., 49: 576 (1970).

15. Fordtran, J. S.: Stimulation of active and passive sodium absorption by sugars in the human jejunum. J. Clin. Invest. 55: 728 (1975).

16. Gilles Baillen, $\mathrm{M} .: \mathrm{Na}^{+}$compartmentation in the jejunal mucosa of the tortoise. In: J. W. L. Robinson: Intestinal Ion Transport, pp 75-78 (M.T.P. Press Ltd., Lancaster U.K., 1976)

17. Goldner, A. M., Schultz, S. G., and Curran, P. F.: Sodium and sugar fluxes across the mucosal border of rabbit ileum. J. Gen. Physiol., 53: 362 (1969)

18. Grady, G. F., Madoff, M. A., Duhamel, R. C., Morre, E. W., and Chalmers, T. C.: Sodium transport by human ileum in vitro and its reponse to cholera enterotoxin. Gastroenterology, 53: 737 (1967).

19. Grand. R. J.. Watkins, J. B., and Torti, F. M.: Development of the human gastrointestinal tract. Gastroenterology, 70: 790 (1976).

20. Kimmich, G. A.: Active sugar accumulation by isolated intestinal epithelial cells. A new model for sodium-dependent metabolite transport. Biochemistry, 9 . 3669 (1970).

21. Kinter, W. B., and Wilson, T. H.: Autoradiographic study of sugar and amino acid absorption by everted sacs of hamster intestine. J. Cell. Biol., 25: 19 (1965).

22. Levin, R. J., Koldovsky, O., Hoskova, J., Jirsova, V., and Uher, J.: Electrical activity across human foetal small intestine associated with absorption processes. Gut., 9: 206 (1968)

23. Lücke, H., Berner, W.. Menge, H., and Murer, H.: Sugar transport by brush border membrane vesicles isolated from human small intestine. Pflugers Arch., 373: 243 (1978)

24. Nellans, H. N., and Schultz, S. G.: Relations among transepithelial sodium transport. potassium exchange, and cell volume in rabbit ileum. J. Gen. Physiol., 68: 441 (1976).

25. Phillips, R. A.: Water and electrolyte losses in cholera. Fed. Proc.. 23: 705 (1964).

26. Preston, R. L.. Schaeffer, J. F., and Curran, P. F.: Structure-affinity relationships of substrates for the neutral amino acid transport system in rabbit ileum. $\mathbf{J}$. Gen. Physiol., 64: 443 (1974).

27. Proverbio, F., Robinson, J. W. L., and Wittembury. G.: Sensitivities of $\left(\mathrm{Na}^{+}+\right.$ $\mathrm{K}^{+}$) - ATPase and $\mathrm{Na}^{+}$extrusion mechanism to ouabain and ethacrynic acid in the cortex of the guinea-pig kidney. Biochim. Biophys. Acta, 211: 327 (1970).

28. Rohde, J. E., and Andersen, B.: In vitro measurement of ion fluxes across biopsies of human jejunal mucosa during cholera. J. Appl. Physiol., 35: 557 (1973)

29. Rothe, C. F., Quay, J. F., and Armstrong, W. M.: Measurement of epithelial electrical characteristics with an automatic voltage clamp device with compensation for solution resistance. IEEE Trans. Bio-Med. Eng., /6: 160 (1969).

30. Schultz, S. G., and Curran, P. F.: Coupled transport of sodium and organic solutes. Physiol. Rev., 50:637 (1970).

31. Schultz, S. G., and Curran, P. F.: Sodium and chloride transport across isolated rabbit ileum. In: F. Bronner and A. Kleinzeller: Current Topics in Membrane and Transport, pp 225-281 (Academic Press, New York, 1974).

32. Schultz. S. G., Curran, P. F., Chez, R. A., and Fuisz, R. E.: Alanine and sodium fluxes across mucosal border of rabbit ileum. J. Gen. Physiol., 50: 1241 (1967).

33. Schultz, S. G., and Zalusky, R.: Ion transport in isolated rabbit ileum. I. Shortcircuit current and Na fluxes. J. Gen. Physiol., 47: 567 (1964)

34. Schultz, S. G., and Zalusky, R.: Ion transport in isolated rabbit ileum. Il. The interaction between active sodium and active sugar transport. J. Gen. Physiol., 47: $1043(1964)$

35. Simmons, N. L., and Naftalin, R. J.: Factors affecting the compartmentalization 
of sodium ion within rabbit ileum in vitro. Biochim. Biophys. Acta. 448: 411 (1976).

36. Stirling, C. E.. Schneider, A. J., Wong, M. D., and Kinter, W. B.: Quantitative radioautography of sugar transport in intestinal biopsies of normal humans and a patient with glucose-galactose malabsorption. J. Clin. Invest., 51: 438 (1972)

37. Tai, Y. H., Desjeux, J. F., Danisi, G., and Curran, P. F.: Na and $\mathrm{Cl}$ transport and short-circuit current in rabbit ileum. J. Membrane Biol.. 31: 189 (1977).

38. The authors thank Miss I. Jolivet and Miss E. Epis for technical assistance and
Dr. C. Tannenbaum for reviewing the manuscript.

39. This research was supported by a Institut National de la Santé et de la Recherche Médicale grant (CRL 77.5.126.7 and A.U. 78.120), by Fondation Echanges et Recherches, and by Fondatin Delessert.

40. Requests for reprints should be addressed to: Dr. J. F. Desjeux, Faculté de Médecine Lariboisière-Saint Louis, 10, Avenue de Verdun, Paris 75010 , France.

41. Received for publication January 6, 1978.

42. Accepted for publication December 21, 1978

Copyright (c) 1979 International Pediatric Research Foundation, Inc.

Printed in U.S.A. $0031-3998 / 79 / 1311-1240 \$ 02.00 / 0$ 